\title{
GLOBAL Distribution OF COCCOLITHOPHORE BLOOMS
}

\author{
By Christopher W. Brown
}

B looms of THE COCCOlithophore Emiliania huxleyi regionally act as an important source of dimethyl sulfide (DMS) and calcium carbonate and alter the optical properties of the surface mixed layer (Balch et al., 1991; Holligan and Balch, 1991). These blooms, often covering vast areas, can be identified in visible satellite imagery because of the large amount of light backscattered from the water column. Their presence gives the ocean a milky white to turquoise appearence. The ability to detect $E$. huxleyi blooms in satellite imagery, in addition to furnishing biogeographical knowledge of the species at time and space scales unattainable with shipboard sampling, provides a method to assess their biogeochemical importance on basin to global scales.

Global composites of Coastal Zone Color Scanner (CZCS) imagery (Feldman et al., 1989) were used to map the distribution pattern of $E$. huxleyi blooms and to estimate the magnitude and periodicity of their $\mathrm{CaCO}_{3}$ and DMS production in the world's oceans (Brown and Yoder, 1994). Pixels of 5-day composite imagery from the entire CZCS mission (November 1978 to June 1986) were classified into either bloom or nonbloom classes based on their mean normalized water-leaving radiances using a supervised, multispectral scheme. This empirically based classification technique is common in terrestrial remote sensing but has only recently been applied by oceanographers. A classification algorithm was developed which compared the spectral signature of known $E$. huxleyi blooms (e.g., Holligan et al., 1983) to spectral signatures of nonbloom conditions. Spectral signatures of E. huxleyi blooms, "clear" blue water, sediment-laden water, "whiting" (suspended lime muds), and atmospheric haze were extracted from CZCS imagery. Decision boundary values for each of five spectral feature characters were assigned

C.W. Brown, Oceans and Ice Branch, Code 971, NASA/Goddard Space Flight Center, Greenbelt, MD 20771, USA; Ph.D. 1993, University of Rhode Island (advisor: James A. Yoder). that would allow the blooms to be spectrally distinguished from the other conditions. An independent data set was also used to establish that the algorithm was effective in distinguishing coccolithophore blooms from the other water conditions, with the exception of whitings, at the spatial resolution of the global imagery. The classified images generated from the scheme were then combined into monthly, annual, and mission climatologies of bloom and nonbloom locations.

Spectral signatures similar to that of E. huxleyi blooms were found to be most extensive at subpolar latitudes, particularly in surface waters of the North Atlantic, the North Pacific, and the Argentine shelf and slope (Figure 1). Classified blooms covered an average of $1.4 \times 10^{6} \mathrm{~km}^{2}$ annually, with the subpolar latitudes accounting for $71 \%$ of this area. The classified blooms at these higher latitudes were inferred to represent the presence of $E$. huxleyi blooms because the classification scheme proved efficient in these regions and their locations are supported by previous biogeographic investigations. Numerous classified blooms, often quite extensive, were also detected in low-latitude marginal seas, though the conditions responsible for this signal are equivocal. Seasonally, the classified blooms in subpolar oceanic regions achieved their greatest spatial extent in summer to early autumn, while those in lower latitudes peaked in midwinter to early spring.

Two important caveats of this approach should be noted. First, the results displayed in Figure 1 reflect the distribution pattern of coccolithophore blooms occurring in the surface layer and are biased toward the declining stage (stationary phase) of the bloom. Detection of blooms is sensitive to light backscattered from approximately one attenuation depth and is primarily a function of detached coccolith concentrations. Blooms composed primary of cells or occurring at depths deeper than that sensed by the CZCS would be missed. Second, the distribution pattern of blooms and their spatial extent are biased by both image coverage and regional atmospheric conditions.
$T$ he ability to detect

E. huxleyi blooms in satellite imagery. . . provides a method to assess their biogeochemical importance on basin to global scales. 


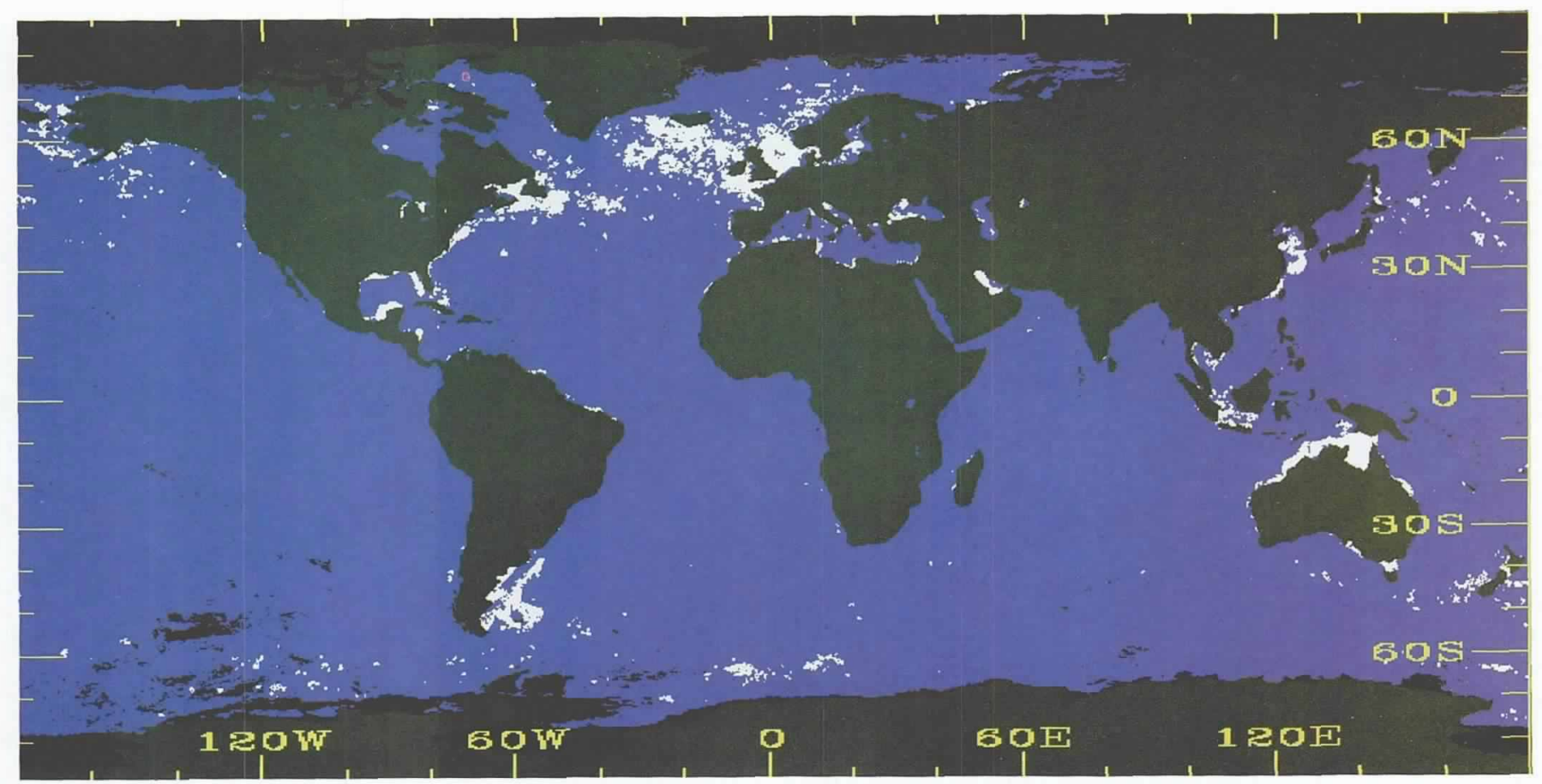

Fig. 1: Mission climatology of classified coccolithophore blooms in the world's oceans. The maximum spatial extent of blooms detected during this period are displayed. Coccolithophore bloom class, white; nonbloom class, blue; land, green; lack of data, black (From Brown and Yoder, 1994).

\section{. . satellite-detected}

blooms play only a

minor role in the

annual production of

calcite and DMS on

a global scale.
The amount of calcite-carbon and DMS-sulfur produced by the classified E. huxleyi blooms was estimated using the mean annual areal extent of the blooms and representative values of mixed layer depth, average cell concentrations found in blooms, DMSP concentration per cell, and mass of calcite per coccolith. The blooms detected at subpolar latitudes $\left(40-60^{\circ}\right)$ are estimated to produce an average of $0.4-1.3 \times 10^{6}$ metric ton $\mathrm{CaCO}_{3}$ carbon and $1 \times 10^{4}$ tm DMS sulfur annually. These standing stock estimates suggest that satellite-detected blooms play only a minor role in the annual production of calcite and DMS on a global scale.

Although no satellite ocean color sensor has operated since the demise of the CZCS in June 1986, future missions, such as the Sea-viewing Wide-Field-of-View Sensor (SeaWiFS), will allow E. huxleyi blooms to be monitored once again. These dedicated ocean color missions, in conjunction with techniques to estimate coccolith and cell concentrations in coccolithophore blooms from satellite imagery (Ackleson et al., 1994), will improve our ability to assess the impact of coccolithophore blooms on the carbon and sulfur cycles in the future.

\section{Acknowledgements}

I thank Jim Yoder for support and guidance throughout my Ph.D. Financial support was provided by a NASA Graduate Student Research Program Fellowship (NGT-50605) and NASA HQ grant NAGW-1891.

\section{References}

Ackleson, S.G., W.M. Balch and P.M. Holligan, 1994: Response of water-leaving radiance to particulate calcite and chlorophyll $a$ concentrations: a model for Gulf of Maine coccolithophore blooms. J. Geophys. Res., 99, 7483-7499.

Balch, W.M., P.M. Holligan, S.G. Ackleson and K.J. Voss, 1991: Biological and optical properties of mesoscale coccolithophore blooms in the Gulf of Maine. Limnol. Oceanogr., 36, 629-643

Brown, C.W. and J.A. Yoder, 1994: Coccolithophorid blooms in the global ocean. J. Geophys. Res., 99, 7467-7482.

Feldman, G., N. Kuring, C. Ng, W. Esaias, C. McClain, J. Elrod, N. Maynard, D. Endres, R. Evans, J. Brown, S. Walsh, M. Carle and G. Podesta, 1989: Ocean color. Availability of the Global Data Set. Eos, 70, 634-635, 640-641.

Holligan, P.M. and W.M. Balch, 1991: From the ocean to cells: coccolithophore optics and biogeochemistry. In: Particle Analysis in Oceanography, S. Demers, ed. SpringerVerlag, Berlin, 301-324.

, M. Viollier, D.S. Harbour, P. Camus and M. Champagne-Philippe, 1983: Satellite and ship studies of coccolithophore production along a continental shelf edge. Nature, 304, 339-342. $\square$ 